\title{
Pengelolaan Wisata Pantai Nambo dalam Meningkatkan Pendapatan Asli Daerah Kota Kendari di Massa Pandemi Covid 19
}

\author{
Erlin, Muhammad Ihsan Mattalitti, Andi Awaluddin Ma'ruf \\ Dinas Kebudayaan dan Pariwisata Kota Kendari, email: erlineing81@gmail.com \\ Program Studi Ilmu Pemerintah, Fakultas Ilmu Sosial dan Ilmu Politik, Universitas \\ Muhammadiyah Kendari, email: ihsan.mattalitti@umkendari.ac.id \\ Program Studi Ilmu Pemerintah, Fakultas Ilmu Sosial dan Ilmu Politik, Universitas \\ Muhammadiyah Kendari, email: andiawaluddin02@gmail.com
}

\begin{abstract}
Abstrak
This study describes how the management of Nambo beach by the Kendari City Culture and Tourism Office to increase regional revenue during the Covid-19 emergency response. Through a qualitative approach, data collection activities are carried out through observation, interviews, document study. The informants in this study were 12 people consisting of the Head of the Service, the Head of the Destination Division, the Head of the Tourism Attraction Section, the Head of the Planning Subdivision, the Beach Manager and the Tourism Awareness Group. The findings of this study indicate that the Nambo beach management process in the aspects of planning the determination of targets and formulation of strategies has been well arranged. Even though the target achievement has not been met due to the decline in the number of visitors to Nambo beach during the Covid 19 pandemic. Furthermore, the organization in terms of the number of staff and the division of duties has not been effective because of the excessive number of staff and also no division of work areas such as the division of staff work areas. encouraging employee work motivation has been effective because the provision of smooth incentives can increase employee morale. Control in terms of comparison between plans and realization has not been effective. Where, in addition to the obligatory factor of levies who are not aware of the importance of paying fees, there is also poor management of traders because they do not know the number of active traders.
\end{abstract}

Keyword : locally-generated revenue, Nambi Bae Retribution, Pantai Nambo 


\begin{abstract}
Abstrak
Penelitian ini menjelaskan tentang bagaimana pengelolaan pantai nambo oleh Dinas Kebudayaan dan Pariwisata Kota Kendari untuk meningkatkan Pendapatan Asil Daerah pada masa tanggap darurat covid-19. Melalui pendekatan kualitatif, aktivitas pengumpulan data dilakukan melalui observasi, wawancara, studi dokumen. Informan dalam penelitian ini berjumlah 12 orang yang terdiri dari Kepala Dinas, Kepala Bidang Destinasi, Kepala Seksi Daya Tarik Wisata, Kasubag Perencanaan, Pengelola Pantai dan Kelompok Sadar Wisata. Temuan penelitian ini menunjukan bahwa proses pengelolaan pantai Nambo pada aspek perencanaan penentuan target dan perumusan strategi telah disusundenganbaik. Sekalipunpencapaian target belum terpenuhi karena menurunnya angka pengunjung pantai Nambo di masa pandemic Covid 19. Selanjutnya pengorganisasian dalam hal jumlah staf serta pembagian tugasnya belum efektif karena jumlah staf yang berlebihan dan juga tidak dilakukan pembagian wilayah kerja seperti dengan pembagian wilayah kerja staf.Adapun memimpin dalam hal mendorong motivasi kerja pegawainya sudah efektif karenapemberian insentif yang lancer dapat meningkatkan semangat kerja pegawai. Pengendalian dalam hal perbandingan rencana dan realisasi belum efektif. Dimana, selain faktor wajib retribusi yang tidak sadar akan pentingnya membayar retribusi juga pengelolaan pedagang yang kurang baik karena tidak diketahuinya jumlah pedagang yang aktif.
\end{abstract}

Kata kunci : Pendapatan Asli Daerah, Retribusi, Pantai Nambo

\title{
Pendahuluan
}

Daerah-daerah di Indonesia diberikan hak otonomi dengan kewenangan yang luas, nyata serta bertanggung jawab dan dapat menjamin perkembangan dan pembangunan daerah. Pemberian kewenangan dimaksud agar dilaksanakan secara proporsional dan diwujudkan dengan pengaturan, pembagian, pemanfaatan sumber daya nasional yang berkeadilan, serta perimbangan keuangan derah dan pusat. Dalam hal ini, kewenangan pada bidang keuangan yang sebelumnya melekat pada pemerintah pusat menjadi kewenangan daerah dalam menjamin terselenggaranya otonomi daerah yang semakin baik, maka diperlukan usaha-usaha untuk meningkatkan lagi kemampuan keuangan sendiri yakni dengan upaya meningkatkan penerimaan Pendapatan Asli Daerah (PAD), baik itu dengan meningkatkan penerimaan sumber PAD yang sudah ada maupun dengan penggalian sumber PAD yang baru sesuai dengan ketentuan yang ada serta memperhatikan kondisi dan potensi ekonomi masyarakat.

Berdasarkan Undang-Undang Nomor 3 tahun 2004, Pendapatan Asli Daerah (PAD) diartikan sebagai penerimaan yang diperoleh daerah dari sumber-sumber dalam wilayahnya sendiri yang dipungut beedasarkan Peraturan Daerah sesuai perundangundangan yang berlaku (Wulandari \& Iriyanie, 2018). PAD juga merupakan salah satu pendapatan yang diperoleh daerah sehingga bisa digunakan dalam rangka mengembangkan dan mengoptimalkan seluruh potensi 
yang ada daerah(Soamole, 2013 ). Salah satu sumber pendapatan asli daerah adalah penerimaan retribusi. Yangmana di dalam penelitian ini difokuskan bersumber dari sektor pariwisata.

Kota Kendari merupakan salah satu daerah yang memiliki aset pariwisata yang bisa dijadikan sebagai sumber-sumber potensial PAD, diantaranya adalah kawasan wisata Kebun Raya Kendari, Tracking Mangrove Bungkutoko, Tracking Mangrove Lahundape, Tahura Nipa-Nipa, Hutan Lindung Nanga-Nanga, Taman Kota, Taman Meohae, Tambat Labu, Taman Kali Kadia, Kuliner Kendari Beach dan kawasan wisata Pantai Nambo. Pantai Nambo yang merupakan kawasan wisata pantai memiliki kondisi fisik yang cukup bagus, terletak di wilayah kelurahan Nambo kecamatan Nambo kota Kendari. Untuk itu kualitas pengelolaan retribusi di kawasan wisata pantai Nambo sangatlah penting dalam rangka meningkatkan Pendapatan Asli Daerah.

Pemungutan tarif obyek retribusi pantai Nambo di kota Kendari diatur dalam Peraturan Daerah (Perda) Nomor 03 Tahun 2012 tentang Retribusi Jasa Usaha dan Peraturan Walikota Nomor 24 Tahun 2017 tentang Penyesuaian Struktur Besaran Tarif Retribusi Tempat Rekreasi dan Olah Raga. Berdasarkan data yang diperoleh sejak dua tahun terakhir yang dikelola oleh Dinas Kebudayaan dan Pariwisata Kota Kendari menunjukkan bahwa angka realisasi retribusi pantai Nambo pada tahun 2018 hampir mencapai setengah dari target yang ditetapkan yaitu sebesar Rp. 171.150.000 atau 69,66\%. Pada tahun 2019 mengalami penurunan realisasi yaitu sebesar Rp. 127.590.000 dengan presentase sebesar 51,04\%.

Ada tantangan baru bagi pengelola pantai Nambo ketika Wordl Health Organization (WHO) mengumumkan status pandemi global untuk penyakit virus corona 2019 atau yang juga disebut corona virus disease 2019 (COVID-19) pada Maret 2020. Yang dilanjutkan dengan dikeluarkannya Peraturan Pemerintah Nomor 21 Tahun 2020 yang mengatur tentang Pembatasan Sosial Berskala Besar (PSBB) sebagai tanggapan terhadap penyakit corona virus disease 2019 (COVID-19) karena telah menjadi pandemi di Indonesia. Hal tersebut kemudian berpengaruh terhadap penerimaan pendapatan retribusi di pantai Nambo karena objek wisata tersebut ikut ditutup sesuai dengan surat edaran Walikota Kendari bernomor 440/845/2020 tanggal 16 Maret 2020.

Berdasarkan masalah di atas dapat disimpulkan bahwa pengelolaan aset wisata pantai Nambo di kota Kendari belum berjalan secara optimal selama pandemi covid 19, baik dalam hal pemungutan retribusi dan pengawasan pelaksanaan pemungutan, pengelolaan pantai Nambo, perkiraan potensi pantai Nambo maupun upaya pemerintah dalam menarik perhatian masyarakat sehingga pendapatan dan penerimaan yang diperoleh tidak mencapai target yang ditetapkan. Mengatasi berbagai masalah yang terdapat dalam pengelolaan pantai Nambo, diperlukan adanya manajemen retribusi pelayanan pantai Nambo sehingga dapat memberikan kontribusi besar terhadap peningkatan pendapatan asli daerah. Dalam hal ini perlu ditunjang dengan pelaksanaan manajemen yang baik karena manajemen dibutuhkan orang-orang bekerja sama untuk mencapai suatu tujuan yang telah ditetapkan. 


\section{Metode Penelitian}

Pendekatan penilitian yang digunakan oleh penulis adalah kualitatif. Yang mana pendekatan ini dianggap sesuai dengan prosedur penelitian karena menghasilkan data deskriptif berupa kata-kata tertulis atau lisan tentang orang-orang, perilaku yang dapat diamati sehingga menemukan kebenaran yang dapat diterima oleh akal sehat manusia (Sugiyono, 2014).

Penelitian ini melibatkan informan sebanyak 12 orang, terdiri dari, Kepala Dinas, Kepala Bidang Destinasi, Kepala Seksi Daya Tarik Wisata, Kasubag Perencanaan, kemudian Pengelola Pantai Nambo 5 orang dan Kelompok Sadar Wisata 3 orang. Teknik pengumpulan data dilakukan melalui observasi lapangan guna memperhatikan mekanisme organisasi dan tata kerja yang berlangsung, selanjutnya melakukan wawancara dengan para informan, dan mengadakan studi dokumen terkait data-data sekuder penelitian.

\section{Hasil Penelitian Dan Pembahasan}

\section{Strategi Pengelolaan Pantai Nambo}

\section{Perencanaan}

Pantai Nambo merupakan salah satu industri jasa strategis di kota Kendari yang menjadi unggulan di bidang pariwisata. Namun kebijakan penanganan pandemi covid 19 telah memberi implikasi pada terjadinya penurunan jumlah pengunjung disebabkan adanya pembatasan aktivitas masyarakat di luar rumah.

Menghadapi wabah pandemic covid 19 dan new normal, Dinas Kebudayaan dan Pariwisata kota Kendari kemudian membuat perencanaan yang lebih strategis, antara lain: (1) himbauan tentang penerapan protocol covid-19; (2) sosialisasi menghadapi new normal; (3) membuat program strategis Disbudpar yang mengacu pada konsep berbudaya, berwisata, dan berkreasi yang diharapkan mampu memberikan efek postif terhadap pariwisata. Selain itu, dilakukan inovasi konsep terhadap obyek wisata pantai Nambo yakni, konsep pantai menjadi konsep wahana air dengan view dan suasana pantai; pengelolaan di pantai nambo dilakukan secara elektronik; melakukan pemberdayaan kelompok sadar wisata di lingkup pantai nambo agar lebih inovatif; dan mendukung terbentuknya UPT agar pengelolaan Pantai Nambo lebih efektif.

Secara operasional melalui bagian Destinasi dan Industri Pariwisata, Disbudpar telah melakukan penetapan target penerimaan retribusi dari pantai Nambo yang tertuang dalam Rencana Kerja Anggaran (RKA). RKA merupakan dasar dalam pembuatan kebijakan umum anggaran kota Kendari setiap tahun.

Temuan penelitian ini menunjukan kurangnya hasil yang diperoleh dari implementasi perencanaan obyek pariwisata pantai Nambo selama masa covid-19. Hal itu terlihat dari hasil pendapatan dan kunjungan wisatawan ke pantai Nambo yang mengalami penurunan. 


\section{Gambar 1. Hasil Pendapatan Dan Kunjungan Di Pantai Nambo Tahun 2020 Berdasarkan Persentase (\%)}

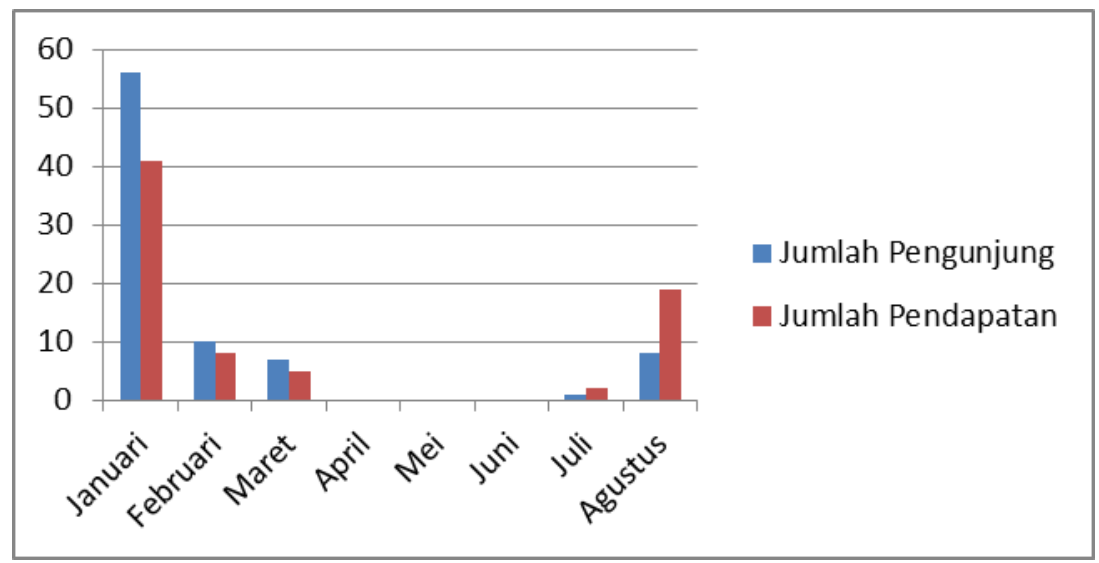

Sumber: Dinas Kebudayaan dan Pariwisata Kota Kendari 2020

Pada gambar di atas terlihat dengan jelas anomali hasil pendapatan dan kunjungan wisatawan ke pantai Nambo pada tahun 2020. Sebelum pandemi covid 19 diumumkan yakni pada bulan januari, jumlah pengunjung mencapai 56\% dan jumlah pendapatan $41 \%$ dari target. Selanjutnya mengalami penurunan hingga mencapai puncak di bulan April, Mei, dan Juni. Hal tersebut terjadi bertepatan dengan dikeluarkannya surat edaran Walikota Kendari Nomor: 440/845/2020 tentang penutupan sementara obyek wisata pantai Nambo.

Kunjungan wisatawan kembali terjadi di bulan Juli pasca keluarnya surat keputusan Walikota Kendari terbaru Nomor 458 tahun 2020 tentang Pembentukan Tim Verifikasi Kesiapan Protokol Kesehatan Covid-19 pada tanggal 30 Juni 2020. Sasaran kebijakan ini adalah tempat usaha kepariwisataan di wilayah kota Kendari yang bermaksud memberi kelonggaran bagi tempat usaha termasuk pada obyek wisata pantai nambo.

\section{Pengorganisasian}

Pengorganisasian dapat didefinisikan sebagai susunan struktur pegawai dan pembagian kerja. Pengorganisasian meliputi pengalokasikan sumber daya dan penetapan tugas pegawai untuk mengatur dan membagi kerja para pegawai di Dinas Kebudayaan dan Pariwisata Kota Kendari. Demikian pula terhadap pemungutan retribusi obyek wisata pantai Nambo. Para pegawai telah dibagi untuk memudahkan proses tersebut.

Secara teknis berdasarkan temuan di lapang, jumlah pemungut retribusi pada obyek wisata Nambo terdiri dari 5 orang staf. 3 orang di bagian loket pintu masuk dan 2 orang staf lainnya di bagian gazebo. Hal ini sesuai dengan Surat Perintah Tugas Nomor 094/212a tentang melaksanakan Tugas Pemungutan Retribusi PAD (karcis masuk dan gazebo) Obyek Pantai Nambo terhitung mulai tanggal 29 Agustus 2020 sampai dengan 31 Desember 2020. 
Tabel 1. Pengelola Pemungut Retribusi PAD Pantai Nambo

\begin{tabular}{cll}
\hline No. & \multicolumn{1}{c}{ Nama } & \multicolumn{1}{c}{ Jabatan } \\
\hline 1. & Ahmadi, S.Tr. Par & Pemungut Retribusi \\
2. & Wulan Supiani, S.I.K & Pemungut Retribusi \\
3. & Erlin & Pemungut Retribusi \\
4. & Farhan Adli, Amd. Par & Pemungut Retribusi \\
5. & Marlan & Pemungut Retribusi \\
\hline
\end{tabular}

Sumber: Dinas Kebudayaan dan Pariwisata Kota Kendari 2020

Temuan penelitian ini menunjukan bahwa pembagian kerja pegawai yang dilakukan oleh Dinas Kebudayaan dan Pariwisata kota Kendari ternyata kurang efektif berdasarkan tugas dan kondisi lokasi pantai Nambo. Tugas para pegawai pada bidang ini cukup banyak, yakni menagih, mencatat, bagian leges dan menampung dana retribusi. Sehingga 5 orang pegawai yang menangani hal ini tidak cukup apalagi jumlah sumber daya manusia yang ada masih banyak. Seharusnya dilakukan kembali pentaan staf pada bagian ini agar mempermudah dan mempercepat proses pemungutan retribusi.

\section{Memimpin}

Memimpin adalah proses memotivasi, mengoordinasikan, dan mendorong individu dan kelompok agar dapat menjalankan tanggungjawabnya dengan penuh kesadaran dan produktifitas yang tinggi untuk mencapai tujuan organisasi. Dalam upaya merealisasikan peningkatan retribusi di obyek wisata pantai Nambo, maka Dinas Kebudayaan dan Pariwisata kota Kendari mendorong motivasi kerja pegawai melalui pemberian insentif.

Pemberian insentif dilakukan pada waktu jaga atau bertugas bagi setiap pegawai. Adapun nominal insentif ditentukan dari berapa total pendapatan yang diperoleh. Pemberian ini diluar dari gaji yang diterima oleh pegawai pada setiap bulannya. Sehingga cukup memberi motivasi dan berimplikasi positif terhadap kinerja kerja mereka.

Namun dalam meningkatkan motivasi kerja, peran pemimpin juga sangat berpengaruh demi kelancaran proses kerja dan kenyamanan kerja para pegawai. Temuan dalam penelitian ini menunjukan bahwa kepemimpinan yang dilakukan oleh kepala Dinas Kebudayaan dan Pariwisara kota Kendari telah berperan dengan baik dalam menerapkan kebijakan yang dapat meningkatkan motivasi dan semangat kerja para pegawai.

\section{Mengendalikan}

Mengendalikan adalah pengawasan untuk melakukan evaluasi terhadap organisasi dalam mencapai tujuannya. Mengendalikan mencakup kelanjutan tugas 
untuk melihat apakah kegiatan-kegiatan dilaksanakan sesuai rencana. Dalam hal ini Dinas Kebudayaan dan Pariwisata Kota Kendari mengukurnya dengan membandingkan antara rencana dan realisasi pendapatannya setiap tahun. Dimana, upaya pemimpin sangat berpengaruh dalam merealisasikan pencapaian tersebut.

Selain pemberian insentif, pihak pimpinan Disbudpar juga aktif melakukan pengarahan dan pemberian motivasi kerja. Sikap ramah dan responsif terhadap keluhan staf yang mendapati kendala dalam proses pemungutan retribusi dinilai sebagai upaya dalam mengoptimalkan kerja staf. Sehingga mereka tidak merasa berjalan sendiri dalam melaksanakan tugas, nyaman dalam bekerja karena tidak merasa berada di bawah tekanan.

Namun kondisi di lapang ditemukan adanya para pemberi retribusi seperti pengunjung dan pedagang yang belum sadar terhadap kebijakan ini, mereka berupaya untuk menghindari atau meminta keringanan kepada petugas pemungut retribusi. Apalagi belum terlihat adanya sikap pemimpin terhadap keadaan ini, sehingga bisa dikatakan kondisi perolehan pendapatan retribusi belum ada peningkatan.

Berdasarkan temuan dalam penelitian ini, maka proses pengendalian kerja secara internal sudah berjalan efektif terutama dalam meningkatkan semangat kerja staf yang memungut retribusi. Hal ini dapat dilihat dari kepemimpinan koordinator Pantai Nambo yang ramah namun tegas dan peduli membuat para pegawai betah sehingga memengaruhi semangat pegawai secara positif. Sekalipun permasalahan masih tetap ada yakni pencapaian target belum pernah terpenuhi.

\section{Simpulan}

Berdasarkan hasil pengamatan hasil wawancara dengan beberapa informan dalam penelitian ini, maka dapat ditarik kesimpulan sebagai berikut :

1. Perencanaan untuk menentukan target dan merumuskan strategi telah disusun dengan baik. Penentuan dan pelaksanaan tahap-tahap dalam mencapai target dilakukan setiap tahun, namun pencapaian target tidak terpenuhi akibat pandemi virus corona (Covid-19) yang menyebabkan kurangnya pengunjung yang datang ke pantai Nambo sehingga retribusi dan realisasi rencana belum terpenuhi.

2. Pengorganisasian atau pembagian kerja pegawai kurang efektif karena pembagian kerja staf tidak disesuaikan dengan pemetaan wilayah kerja. Selain itu juga tidak disesuaikan dengan porsi kerja tim yang bertugas.

3. Memimpin dalam hal mendorong motivasi kerja pegawainya sudah efektif karena pemberian insentif yang lancar dapat meningkatkan semangat kerja pegawai.

4. Pengendalian dalam hal perbandingan rencana dan realisasi belum efektif. Dimana, selain faktor wajib retribusi yang tidak sadar akan pentingnya membayar retribusi juga pengelolaan pedagang yang kurang baik karena tidak diketahuinya jumlah pedagang yang aktif menyebabkan target dalam artian rencana dengan realisasi terkadang meningkat dan menurun serta target tidak pernah tercapai. 


\section{Saran}

Adapun saran yang dapat penulis berikan dalam penelitian ini adalah sebagai berikut :

1. Aspek perencanaan, sebaiknya perencanaan tidak diikuti oleh janji- janji pemerintah

2. Aspek pengorganisasian, sebaiknya dilakukan pengoptimalan jumlah pegawai atau bisa dilakukan pembagian wilayah kerja terhadap setiap staf untuk mempermudah dan mempercepat proses pemungutan retribusi.

3. Aspek memimpin, sebaiknya pemberian motivasi pegawai jangan hanya mengandalkan intensif, namun harus ada ide-ide kreatif oleh pemimpin yang bisa meningkatkan semangat kerja pegawainya.

4. Aspek mengendalikan, sebaiknya dilakukan musyawarah kepada semua wajib retribusi untuk memberikan sosialisasi tentang pentingnya membayar retribusi, juga sebaiknya dibuat data nama para pedagang aktif agar realisasi pendapatan retribusi bisa lebih terukur.

\section{Referensi}

Soamole, M. (2013). Pengaruh Pendapatan Asli Daerah (PAD) Terhadap Penyelenggaraan Pembangunan Daerah (Suatu Studi di Kabu. Kepulauan Sula. Governance,https://ejournal.unsrat.ac.id/index.php/governance/article/view/1029

Sugiyono. (2014). Metode Penelitian Kuantitatif, Kualitatif, dan R \& D. CV. Alfabeta.

Wulandari, A. P., \& Iriyanie, E. (2018). Pajak Daerah dalam Pendapatan Asli Daerah. Deepublish.

\section{Peraturan Perundang-Undangan:}

Undang-Undang Dasar Negara Republik Indonesia 1945.

Undang-Undang Nomor 33 Tahun 2004 Tentang Perimbangan Keuangan Pemerintah Pusat dan Pemerintah Daerah.

Undang-Undang Nomor 28 Tahun 2007 Tentang Ketentuan Umum dan Tata Cara Perpajakan.

Undang-Undang Nomor 10 Tahun 2009 Tentang Kepariwisataan.

Undang-Undung Nomor 28 Tahun 2009 Tentang Pajak Daerah dan Retribusi Daerah.

Undang-Undang Nomor 23 Tahun 2014 Tentang Pemerintah Daerah.

Peraturan Pemerintah Nomor 66 Tahun 2001 Tentang Retribusi Daerah.

Peraturan Daerah (Perda) Nomor 03 Tahun 2012 Tentang Retribusi Jasa Usaha 
Peraturan Walikota Kendari Nomor 47 Tahun 2016 Tentang Kedudukan, Susunan Organisasi, Tugas Dan Fungsi Serta Tata Kerja Dinas Kebudayaan dan Pariwisata Kota Kendari.

Peraturan Walikota Nomor 24 Tahun 2017 Tentang Penyesuaian Struktur Besaran Tarif Retribusi Tempat Rekreasi dan Olah Raga. 